\title{
RADIOMETRIC DATING OF YOUNG AND OLD CALCRETE
}

MEBUS A. GEYH

Niedersächsisches Landesamt für Bodenforschung, P.O. Box 51 0153, D-30631 Hannover, Germany

and

BERNHARD EITEL

Physische Geographie, Universität Passau, Schusterstr. 21, D-94032 Passau, Germany

ABSTRACT. To obtain a better understanding of the relationship between calcrete genesis and the results of different absolute dating methods, thermoluminescence (TL), radiocarbon $\left({ }^{14} \mathrm{C}\right)$ and uranium/thorium $(\mathrm{U} / \mathrm{Th})$ were applied to coeval samples taken from a very young calcrete profile in Namibia. The methodically different ages reflect the characteristics of the applied dating methods, the genetics of calcrete and different events of calcrete genesis. The conventional ${ }^{14} \mathrm{C}$ ages and the TL dates cover the last $50 \mathrm{ka}$, while the corresponding $U / T h$ dates of coeval samples are many times larger. Uranium-series dates are not related to the deposition of the host material or to its cementation if the ages are smaller than ca. $120 \mathrm{ka}$. The TL clock is set to zero during eolian transport and the corresponding radiometric ages of the quartz and feldspar grains date the time of their deposition. The ${ }^{14} \mathrm{C}$ ages of the cement correspond, on the other hand, to a time shortly after the onset of the cementation and long before its termination. In the case of very old calcrete, the mixture of young and old cement results in ambiguous ages if they cannot be confirmed by an independent technique.

\section{INTRODUCTION}

\section{Formation of Calcretes}

Calcrete is found worldwide in semi-arid and arid regions, often in thick layers. It is formed by "accumulation of carbonate within a regolith at any stage of development" (Netterberg 1978). This has been occurring in Namibia since at least the late Tertiary. The rate of calcrete formation depends on the precipitation rate within this environment.

Calcrete formation involves cementation or replacement of eolian or fluviatile material (e.g., fragments of dolomite, calcite, iron oxide, silica and calcium phosphate minerals, basalt or granite clasts, fine-grained quartz, feldspar and clay minerals). In Namibia most of the calcium carbonate of the cement is secondary, usually eroded from exposed calcrete or limestone and transported over considerable distances. The eolian calcareous detritus that has accumulated on the surface since the last storm is dissolved and infiltrated by rain water in the host sediment (Blümel 1982; Eitel 1994). During seepage through fractures and pores of the sediment, this water evaporates, leaving behind its dissolved load of inorganic carbon (TDIC). In the initial stage of calcrete formation calcareous nodules are formed, which are slowly cemented together, forming very compact layers. The penetration depth of the water depends on the intensity of the rain, whereas deposition of the cement does not. Only the induration rate is governed by the amount of rain. Subsequent denudation, exposure, erosion, superficial dissolution and weathering of the exposed calcrete results in diagenesis, hardening of the crust surface and filling of voids. In the final stage-generally after erosion and exposure - calcrete may be altered diagenetically into duricrust (hardpan calcrete). Hence, calcrete profiles usually contain many components with different ages and represent various stages of carbonate formation (Blümel 1991).

According to Eitel (1995) Tertiary calcrete in Namibia is continuously eroded and the calcareous, fine-grained detritus is transported by wind over large distances to new deposition sites (Fig. 1). These sediments may have undergone multiple fluvial reworking but eventually rainwater or groundwater dissolves the $\mathrm{CaCO}_{3}$, seeps into the host material and evaporates. Cementation takes place. 


\section{Principles of the Dating of Calcrete}

The most comprehensive paper written on the relationship between calcrete genesis and radiometric dating is by Netterberg (1978). Many of his statements are still valid, although those on the suitability of the various radiometric dating methods for calcrete age determination have to be revised or critically discussed. In general, the two most important times for the dating of calcrete formation are the time of deposition of the host material and "the first onset of its cementation" (Netterberg 1978).

Numerous methods have been recommended for dating calcrete (Netterberg 1978), although most of the results are ambiguous: apparent radiocarbon ages of old calcrete cover the entire range of the dating method up to $c a$. $50 \mathrm{ka} \mathrm{BP}$, while the corresponding uranium/thorium (U/Th) ages of coeval samples are many times larger. This discrepancy is explained by contamination with recent ${ }^{14} \mathrm{C}$ and/or uranium leaching as well as accumulation resulting in apparently lowered ${ }^{14} \mathrm{C}$ ages and apparently increased or lowered, unreasonable U/Th dates. In no case have the explanations been based on facts.

${ }^{14} \mathrm{C}$ dates of the cement are related to the ${ }^{14} \mathrm{C}$ value of the TDIC in the pore water. As the ${ }^{14} \mathrm{C}$ value of the TDIC in groundwater is lower than that of atmospheric $\mathrm{CO}_{2}$, the ${ }^{14} \mathrm{C}$ ages of the secondary carbonate might be too large by several 100 to $1000 \mathrm{yr}$ (reservoir effect). The older the groundwater, the larger the deviation can be. But, the difference between the actual age of the cement and the conventional ${ }^{14} \mathrm{C}$ date of TDIC can also be considerably diminished by redissolution and reprecipitation of the cement as in polygenetic calcrete. ${ }^{14} \mathrm{C}$ ages will not be reasonable if the host material consists of calcareous sediment, which cannot be separated from the cement.

${ }^{230} \mathrm{Th} /{ }^{234} \mathrm{U}$ ages of the cement could reflect the time of onset of induration if only uranium in the descending groundwater is precipitated in the calcrete cement. In the other extreme case the dates may correspond to the age of the eroded carbonate dust.

Thermoluminescence (TL) and Optically Stimulated Luminescence (OSL) dates determined on feldspar and guartz grains of the host sediment are considered as reliable and date the time of its deposition. It is assumed that the TL clock of the mineral grains is reset to zero during eolian transport and exposure to UV light before burial. There is no relationship to the time of cementation.

Electron spin resonance (ESR) dates are not considered here because basic problems with the method have not yet been solved and international cross checks have not yet been sufficiently successful (Hennig, Geyh and Grün 1985; Barabas et al. 1993).

Paleomagnetic dating of calcrete is recommended but its suitability has not yet been verified. The main problem seems to be that the geomagnetic signals of both the host material and the cement are superimposed. The K/Ar and fission-track methods have been suggested for dating pre-Quaternary calcrete (Netterberg 1978), although only the age of the host material rather than the time of its deposition or cementation can be determined.

\section{STUDY AREA AND DATED MATERIAL}

The sampling location is situated some kilometers south of Khorixas (Fig. 1) where fine-grained sediments fill a basin at the Dieprivier and Uitskot farms up to $>5 \mathrm{~m}$. At present, an ephemeral AbaHuab tributary erode the deposits forming local badland-type surfaces. The profile shows early stages of induration. The degree of cementation increases with increasing depth (Table 1). The host material consists of non-calcareous material. The carbonate is allochthonous. It was initially assumed that the source material of the calcrete cement was of marine origin and that the ${ }^{234} U /{ }^{38} U$ activity ratios were ca. 1.15. Two samples of unconsolidated sediment were analyzed, yielding 
ratios of 3.17 and 5.05. Such values are characteristic of secondary carbonate. This fits in the genetic concept for pedogenic calcrete formation in Namibia by Eitel (1994): An exposed Tertiary calcrete in a considerable distance east of the basin is eroded and the resulting calcareous detritus is transported-above all by wind-to the new deposition areas. There it contributes to the formation of a younger calcrete generation.

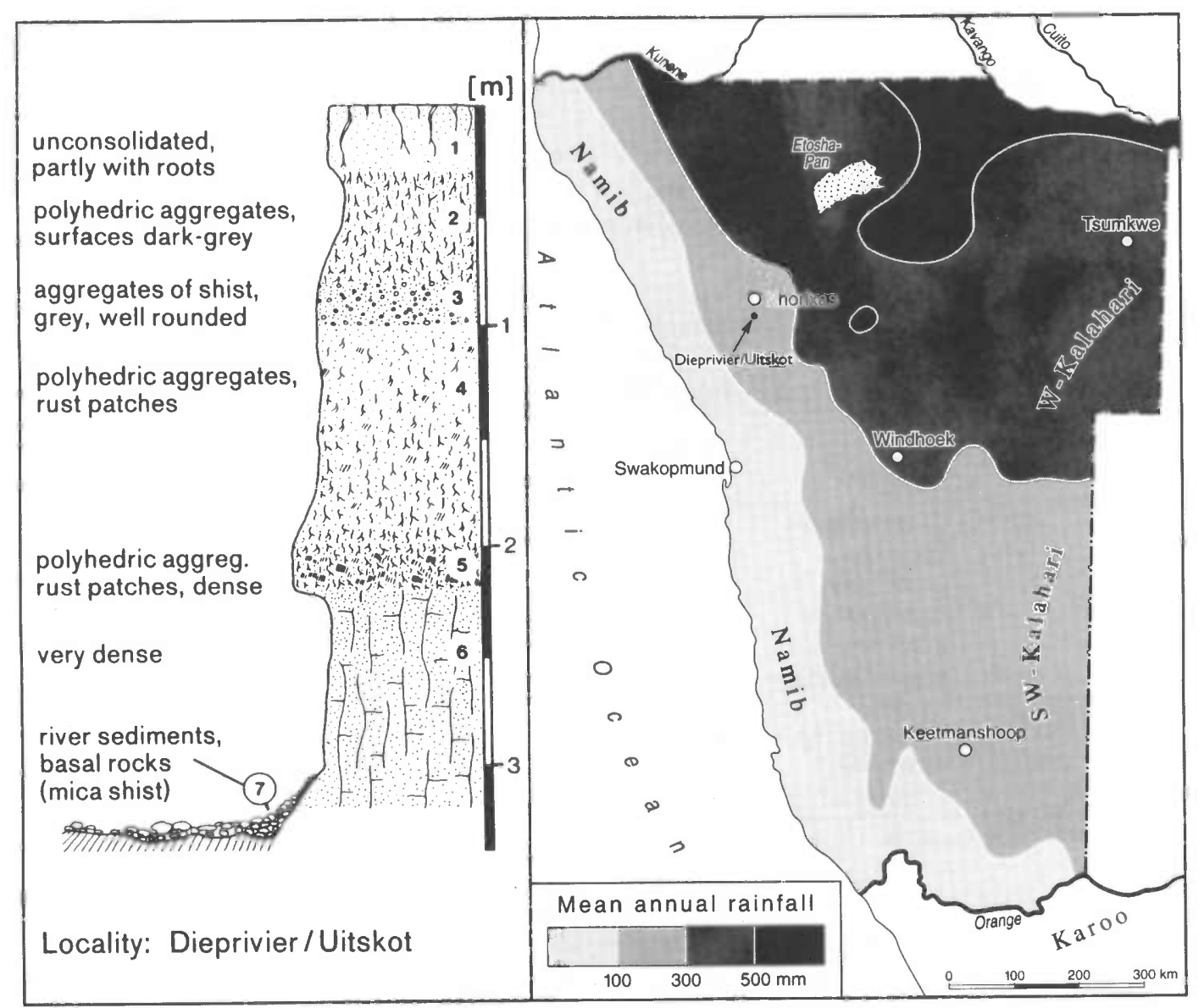

Fig. 1. Left: the structure of the calcrete profile in the investigated basin near the Farm Uitskot (after Eitel and Zöller 1996). Right: localization of the sampling site south of Khorixas with a present mean annual rainfall of $250 \mathrm{~mm}$.

\section{METHODS AND RESULTS}

For a better understanding of the genesis of calcrete and its influence on the results of three complementary radiometric dating methods- $-\mathrm{TL},{ }^{14} \mathrm{C}$ and $\mathrm{U} / \mathrm{Th}-$ the corresponding ages of coeval samples from the same calcrete profile in northwestern Namibia were determined.

${ }^{14} \mathrm{C}$ dating was carried out on the total carbonate fraction of the samples by means of proportional counters filled with acetylene as counting gas. Conventional ${ }^{14} \mathrm{C}$ dates are given according to the definition by Stuiver and Polach (1977).

Uranium and thorium have been extracted in the common way (Ivanovich and Harmon 1993) after decomposition the bulk samples by acids. Ion exchange separation was followed by electrolytic dep- 
osition on stainless steel plates. Alpha spectrometric measurements were done with four Packard germanium detectors connected to a multichannel analyzer. The radiometric results are compiled in Table 2. The ${ }^{234} \mathrm{U} /{ }^{238} \mathrm{U}$ activity ratio ranges from 1.82 to 3.33 .

The sedimentological and mineralogical characteristics of the samples studied by the TL method and their pedogenic features were published by Eitel and Zöller (1996). For TL dating, the 4-11 $\mu \mathrm{m}$ fine grain fraction was extracted. From sample 6 only the $90-200 \mu \mathrm{m}$ coarse quartz grain fraction yielded sufficient material for TL measurements. All sample aliquots were subject to a $1 \mathrm{~min}$ preheat at $250^{\circ} \mathrm{C}$ in order to remove unstable TL components. The TL was measured at a rate of $5^{\circ} \mathrm{C} \mathrm{s}^{-1}$ up to $500^{\circ} \mathrm{C}$ using an EMI $9635 \mathrm{Q}$ photomultiplier with a blue-transmittant Corning 5-58 filter glass. The specific radioactivities of $U$, Th and $\mathrm{K}$ were determined by thick source alpha-counting, GeigerMüller beta-counting, atomic absorption analysis and high resolution gamma-spectrometry with a pure Ge planar detector. The results (Table 3) were consistent within 1- $\sigma$ errors (for further details see Eitel and Zöller 1996).

TABLE 1. Structure, petrographic composition, TL (Eitel and Zöller 1995, 1997), conventional ${ }^{14} \mathrm{C}$, as well as uncorrected and corrected ${ }^{230} \mathrm{Th} /{ }^{34} \mathrm{U}$ ages of sediments in the basin at the Dieprivier and Uitskot farms. The detritic correction of the $\mathrm{U} / \mathrm{Th}$ age was done using a ${ }^{230} \mathrm{Th} / 232 \mathrm{Th}$ activity ratio of 1.

\begin{tabular}{|c|c|c|c|c|c|c|c|}
\hline \multirow{2}{*}{$\begin{array}{c}\text { Sample } \\
\text { no. }\end{array}$} & \multirow{2}{*}{$\begin{array}{l}\text { Depth } \\
\text { (cm) }\end{array}$} & \multirow[b]{2}{*}{ Material ${ }^{*}$} & \multirow{2}{*}{$\begin{array}{c}\mathrm{TL} \text { age } \\
(\mathrm{ka})\end{array}$} & \multirow{2}{*}{$\begin{array}{l}{ }^{14} \mathrm{C} \text { age } \\
\text { (yr BP) }\end{array}$} & \multirow{2}{*}{$\begin{array}{c}\text { Difference } \\
(y r)\end{array}$} & \multicolumn{2}{|c|}{${ }^{230} \mathrm{Th} /{ }^{234} \mathrm{U}$ age (ka) } \\
\hline & & & & & & Uncorrected & Corrected \\
\hline 1 & $0-30$ & Unconsolidated & $8.2 \pm 0.6$ & $2325 \pm 150$ & $5875 \pm 640$ & $206 \pm 14$ & $160 \pm 19$ \\
\hline $1 \mathrm{a}$ & $30-40$ & Loose, p.a. & $11.4 \pm 1.4$ & & & $>250$ & $>250$ \\
\hline 2 & $40-65$ & Loose, p.a. & $12.3 \pm 0.7$ & & & $83 \pm 4$ & $63 \pm 4$ \\
\hline 3 & $75-100$ & $\begin{array}{l}\text { Aggregates of } \\
\text { schist fragments, } \\
\text { rounded pebbles }\end{array}$ & $13.5 \pm 0.8$ & $10,850 \pm 255$ & $2650 \pm 840$ & $98 \pm 7$ & $75 \pm 7$ \\
\hline 4 & $115-135$ & P.a., r.p. & $21.6 \pm 1.9$ & & & $74 \pm 4$ & $56 \pm 5$ \\
\hline 5 & $195-220$ & Dense, p.a., r.p. & $29.5 \pm 1.8$ & $20,090 \pm 680$ & $9410 \pm 1930$ & $79 \pm 3$ & $62 \pm 3$ \\
\hline 6 & $235-260$ & $\begin{array}{l}\text { Very dense, } \\
\text { slightly fractured }\end{array}$ & $29.5 \pm 22$ & & & $68 \pm 6$ & $45 \pm 7$ \\
\hline
\end{tabular}

TABLE 2. Results of the Uranium and Thorium Analyses from the Sediments in the Basin at the Dieprivier and Uitskot Farms

\begin{tabular}{cccccc}
\hline Sample no. & $\begin{array}{c}\text { Depth } \\
(\mathrm{cm})\end{array}$ & $\begin{array}{c}\mathrm{U} \\
(\mathrm{ppb})\end{array}$ & $\begin{array}{c}\mathrm{Th} \\
(\mathrm{ppb})\end{array}$ & ${ }^{234} \mathrm{U} /{ }^{238} \mathrm{U}$ & ${ }^{230} \mathrm{Th} /{ }^{32} \mathrm{Th}$ \\
\hline 1 & $0-30$ & 555 & 1370 & 1.82 & 2.1 \\
$1 \mathrm{a}$ & $30-40$ & 215 & 575 & 1.92 & 2.7 \\
2 & $40-65$ & 545 & 830 & 2.56 & 2.9 \\
3 & $75-100$ & 305 & 565 & 2.75 & 2.9 \\
4 & $115-135$ & 1410 & 2180 & 2.93 & 3.0 \\
5 & $195-220$ & 1060 & 3330 & 3.33 & 3.3 \\
6 & $235-260$ & 2365 & 3260 & 2.16 & 2.4 \\
\hline
\end{tabular}

\section{RESULTS}

The dates determined by the ${ }^{14} \mathrm{C}, \mathrm{U} / \mathrm{Th}$ and TL methods are compiled in Table 1 . Both TL and ${ }^{14} \mathrm{C}$ dates increase and the U/Th ages decrease with increasing depth. TL ages are ca. 3000-9000 yr larger than the conventional ${ }^{14} \mathrm{C}$ dates. The $\mathrm{U} / \mathrm{Th}$ ages are by more than several ten thousands of years older. 
The alpha spectrometric results for the uranium/thorium dating of the various samples are compiled in Table 3. If the ${ }^{230} \mathrm{Th} /{ }^{232} \mathrm{Th}$ activity ratios are below 10 , the corrected and uncorrected $\mathrm{U} / \mathrm{Th}$ ages deviate from each other (Table 1). For the detritic corrections, an initial ${ }^{230} \mathrm{Th} /{ }^{232} \mathrm{Th}$ ratio of unity was assumed.

TABLE 3. Radiometric Results and TL Data of the Sediments in the Basin at the Dieprivier and Uitskot Farms*

\begin{tabular}{cccccccc}
\hline Sample & $\begin{array}{c}\mathrm{U} \\
(\mu \mathrm{g} / \mathrm{g})\end{array}$ & $\begin{array}{c}\mathrm{Th} \\
(\mu \mathrm{g} / \mathrm{g})\end{array}$ & $\begin{array}{c}\mathrm{K} \\
(\%)\end{array}$ & $\begin{array}{c}\mathrm{d} \\
(\mathrm{Gy} / \mathrm{ka})\end{array}$ & $\begin{array}{c}\mathrm{ED}_{\beta} \\
(\mathrm{Gy})\end{array}$ & $\begin{array}{c}\text { Plateau } \\
\left({ }^{\circ} \mathrm{C}\right)\end{array}$ & $\begin{array}{c}\text { TL age } \\
(\mathrm{ka})\end{array}$ \\
\hline 1 & 4.38 & 12.89 & 2.72 & 6.27 & $51.3 \pm 2.8$ & $300-450$ & $8.2 \pm 0.6$ \\
2 & 3.82 & 12.85 & 2.77 & 6.18 & $75.9 \pm 2.7$ & $320-360$ & $12.3 \pm 0.7$ \\
3 & 4.67 & 11.95 & 2.99 & 6.87 & $92.7 \pm 1.9$ & $300-380$ & $13.5 \pm 0.8$ \\
4 & 4.96 & 11.62 & 2.50 & 6.68 & $145 \pm 9.3$ & $320-420$ & $21.6 \pm 1.9$ \\
5 & 4.72 & 11.68 & 2.74 & 6.66 & $197 \pm 4.7$ & $325-395$ & $29.5 \pm 1.8$ \\
6 & 5.85 & 12.94 & 2.09 & 4.74 & $140 \pm 103$ & $280-420$ & $29.5 \pm 22$ \\
\hline
\end{tabular}

*d=dose rate; $\mathrm{ED}=$ beta equivalent dose

\section{DisCUSSION AND CONCLUSION}

The interpretation of the radiometric dating results (Table 1) is based on Eitel's (1994) conception of calcrete formation and aspects of the absolute dating methods used (Geyh and Schleicher 1990).

The ${ }^{230} \mathrm{Th} /{ }^{234} \mathrm{U}$ ages for the sample from the top layer may correspond to that of the calcareous source material. Both $\mathrm{U} / \mathrm{Th}$ ages may be elevated due to leaching of uranium. ${ }^{234} \mathrm{U}$ is dissolved preferentially (Ivanovich and Harmon 1993) and may be deposited later deeper in the calcrete profile. This has apparently occurred in the analyzed profile. The ${ }^{234} \mathrm{U} /{ }^{38} \mathrm{U}$ activity ratio and the $\mathrm{U}$ content increase with depth from 1.8 to 3.3 and 215 to $2365 \mathrm{ppb}$, respectively. The U/Th ages decrease correspondingly. As this uranium leaching and reaccumulation is not age dependent, the $U / T h$ dates are not related to either the time of deposition of the host sediment or to that of the onset or termination of the cementation. The exceptionally low ${ }^{234} \mathrm{U} /{ }^{238} \mathrm{U}$ activity ratio and $\mathrm{U} / \mathrm{Th}$ age of 2.2 and $9400 \mathrm{yr}$, respectively, of the bottom layer of this profile may be attributed to uranium leaching and accumulation related to episodic runoff in this wadi. Evidently, the U/Th dates in deep parts of calcrete profiles decrease to a minimum. Afterwards, the U/Th date will increase if the calcrete behaves as a closed system. That means that U/Th dates for very old calcrete may reflect the age of the last cementation plus an unknown minimum age.

The ${ }^{234} \mathrm{U} /{ }^{238} \mathrm{U}$ activity ratios of two unconsolidated sediment samples are 3.17 and 5.05, respectively. Such values are characteristic of secondary carbonate. This supports the genetic concept for calcrete formation by Eitel (1994). Exposed Tertiary calcrete a considerable distance away is eroded and the resulting calcareous detritus is transported by wind to new deposition areas far away. There it contributes to the formation of mono- and polygenetic calcrete. Initially it was assumed that the source material of the calcrete cement was of marine origin which has a ${ }^{234} U /{ }^{238} \mathrm{U}$ activity ratio of $1.15 \pm 0.01$.

The conventional ${ }^{14} \mathrm{C}$ age of newly formed cement can correspond to that of the TDIC of the descending or ascending water. Due to the reservoir effect the date for the precipitated secondary carbonate is expected to be too old by up to $1000 \mathrm{yr}$. The dating result of the top layer shows, however, that the ${ }^{14} \mathrm{C}$ clock is reset to nearly zero during dissolution of the calcareous detritus and the precipitation of the cement. Evidently, biogenic $\mathrm{CO}_{2}$ in the top sediment completely isotopically 
exchanges with the $\mathrm{HCO}_{3}$ - of the pore water in the host sediment. That means that ${ }^{14} \mathrm{C}$ dates should date the onset of cementation with an uncertainty of a few hundred years. As multiple dissolution and precipitation is usual, however, a later date is normally obtained. In the final stage, the time of alteration of the calcrete into duricrust (hardpan calcrete) may be obtained. Our ${ }^{14} \mathrm{C}$ ages show that they date the time near the beginning of cementation rather than its termination.

This statement has to be modified for very dense, presumably very old calcrete. As pores and cracks are continuously formed in calcrete and filling of voids with cement is nearly independent of climate, the cement of very old calcrete consists of components of different ages. $\mathrm{A}^{14} \mathrm{C}$ date can be calculated from the corresponding ${ }^{14} \mathrm{C}$ value of such material but it cannot be interpreted as an age. Hence, ${ }^{14} \mathrm{C}$ ages $>25$ or $30 \mathrm{ka} \mathrm{BP}$, corresponding to only 4.5 to $2.3 \%$ of modern carbonate in the old cement, are only meaningful if they can be confirmed by an independent method, e.g., the TL method.

The TL dates were determined on the quartz fraction of the fine-grained sediment (Eitel 1995; Geyh 1995; Eitel and Zöller 1995, 1997). It is assumed that the TL clock was set to zero during eolian transport of the detritus. Long TL age plateaus and the stratigraphic consistency of the TL results support this assumption (Eitel and Zöller 1995). The TL ages date the time of deposition rather than any time during the cementation history of the host sediment. As a small, non-bleachable, residual TL intensity could not be completely excluded, the TL ages might be somewhat too high. Application of the OSL method may overcome this problem in future. In the case of old calcrete, the difference between the time of deposition of host material and the onset of cementation may be of no importance. The range of a reliable TL dating is restricted to ca. $100 \mathrm{ka}$ at present (Wintle 1987; Wintle et al. 1993), but may be extended in the future (Berger, Pillans and Palmer 1992). In any case, TL dates should always be higher than ${ }^{14} \mathrm{C}$ dates.

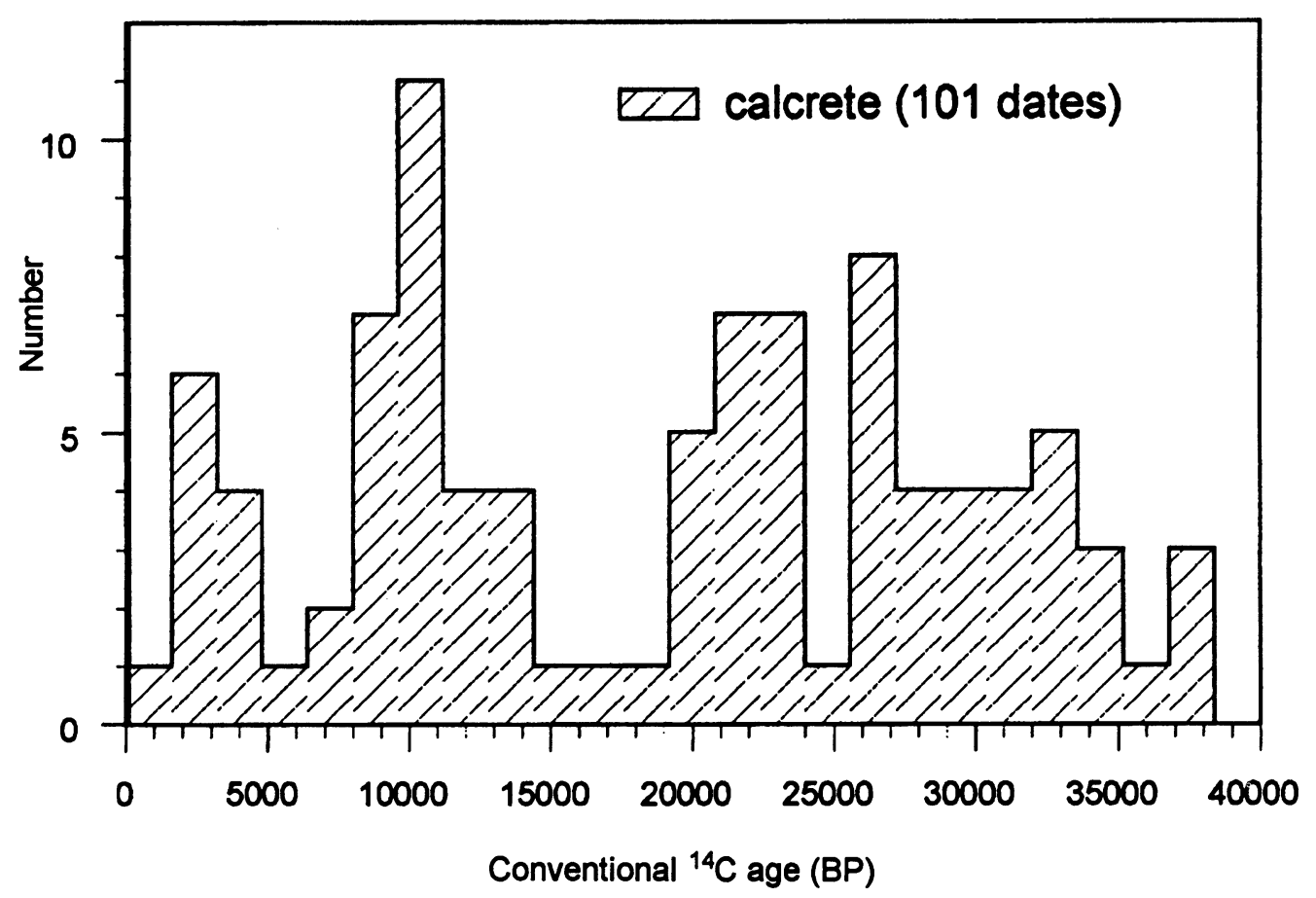

Fig. 2. Histogram of conventional ${ }^{14} \mathrm{C}$ dates (Thomas and Shaw 1991) determined for calcrete from the Kalahari region 
The TL dates from the eastern border of the Namib desert have been interpreted as a reflection of four phases of sedimentation subsequent to previous erosion at the Basin at Dieprivier/Uitskot at $c a$. $30 \mathrm{ka} \mathrm{BP}, c a .20 \mathrm{ka} \mathrm{BP}$, before $13 \mathrm{ka} \mathrm{BP}$, and at $8 \mathrm{ka} \mathrm{BP}$ (Eitel and Zöller 1995, 1996). The sedimentation during the marine $\delta^{18} \mathrm{O}$ Stage 2 might had been due to reduced rainfall rates and intensities. The Aba-Huab affluent did not approach the strength for erosion as it did before. Initial pedogenesis characterized by carbonization and hydromorphic features mark the three intercalated, most likely some more humid periods of geomorphic stability (Eitel and Zöller 1996). It is under dispute whether the changing geomorphodynamics has been due to an oscillating Benguela upwelling or hygric fluctuations of the monsoonal summer rain.

The histogram of 101 conventional ${ }^{14} \mathrm{C}$ dates (Fig. 2) for calcrete taken from a publication by Thomas and Shaw (1991) confirms this chronology and the described chronological concept. The ${ }^{14} \mathrm{C}$ dates are always smaller than the corresponding TL ages, and the first induration of the loose host sediment needs several thousand years. Our results fit in this picture (Geyh 1995).

In summary, ${ }^{14} \mathrm{C}$ dating of young calcrete yields a reliable chronological framework for the history of its formation, in contrast to the conclusions by Eitel and Zöller (1996). ${ }^{14} \mathrm{C}$ dates for calcrete cement correlate closely with the onset of cementation and far from the termination of this process. If this time difference is small the reservoir correction of up to a few hundred years is negligible. In the case of ${ }^{14} \mathrm{C}$ dating of very old calcrete, independent radiometric dating methods should be used to confirm or disprove the apparent ages. OSL rather than TL dates may reflect the time of deposition of the host material within an age range of $c a .100 \mathrm{ka}$ (Wintle 1987). Older samples might become datable in the future (Berger, Pillans and Palmer 1992; Wintle et al. 1993). Somewhat high TL ages are obtained in the case of overbleaching. U/Th dates are not related to either the period of the deposition of host material or to that of its cementation. Paleomagnetic dating is questionable because the magnetization of the host material and that of the cement are superimposed and cannot be separated from each other. Moreover, diagenesis of the cement may replace the host material and distort the original paleomagnetic signal.

\section{REFERENCES}

Barabas, M., Walther, R., Wieser, A., Radtke, U. and Grün, R. 1993 Second interlaboratory-comparison project on ESR dating. Applied Radiation \& Isotopes 44: 119-129.

Berger, G. W., Pillans, B. J. and Palmer, A. S. 1992 Dating loess up to $800 \mathrm{ka}$ by thermoluminescence. Geology 20: 403-406.

Blümel, W. D. 1982 Calcretes in Namibia and SE Spain relations to substratum, soil formation and geomorphic factors. Catena Supplement 1: 67-82.

Blümel, W. D. 1991 Kalkkrusten - ihre genetische Beziehungen zu Bodenbildungen und äolischer Sedimentation. Geomothodica 16: 169-197.

Eitel, B. 1994 Kalkreiche Decksedimente und Kalkkrustengenerationen in Namibia: Zur Frage der Herkunft und Mobilisierung des Calciumcarbonats. Stuttgarter Geographische Studien 123: 193 p.

1995 Kalkkrusten in Namibia und ihre paläoklimatische Interpretation. Geomethodica 20: 101-124.

Eitel, B. and Zöller, L. 1995 Die Beckensedimente von Dieprivier und Uitskot (NW-Namibia): Ein Beitrag zu ihrer paläoklimatischen Interpretation auf der Basis

von Thermolumineszenzdatierungen. Mitteilungen der Österreichischen Geographischen Gesellschaft 137: 245-254.

1996 Soils and sediments in the basin of Dieprivier - Uitskot (Khorixas District, Nambia): Age, geomorphic and sedimentological investigation, paleoclimatic interpretation. Palaeoecology of A frica 24: 159172.

Geyh, M. A. 1995 Geochronologische Aspekte paläohydrologischer und paläoklimatischer Befunde in Namibia. Geomethodica 20: 75-99.

Geyh, M. A. and Schleicher, H. 1990 Absolute Age Determination. Physical and Chemical Dating Methods and Their Application. Berlin, Springer-Verlag: $503 \mathrm{p}$.

Hennig G. J., Geyh, M. A. and Grün R. 1985 The first interlaboratory ESR comparison project phase II: Evaluation of equivalent doses (ED) of calcites. Nuclear Tracks 10: 945-952.

Ivanovich, M. and Harmon, R. S., eds. 1993 Uranium Series Disequilibrium. Applications for Environmental Problems. Oxford, Clarendon: $571 \mathrm{p}$.

Netterberg, F. 1978 Dating and correlation of calcretes 
and other pedocretes. Transactions of the Geological Society of South Africa 81: 379-391.

Stuiver, M. and Polach, H. A. 1977 Discussion: Reporting of ${ }^{14} \mathrm{C}$ data. Radiocarbon 19(3): 355-363.

Thomas, D. S. and Shaw, P. A. 1991 The Kalahari Environment. Cambridge, Cambridge University Press: $284 \mathrm{p}$.
Wintle, A. G. 1987 Thermoluminescence dating of loess. Catena Supplement 9: 103-115.

Wintle, A. G., Questiaux, D. G., Roberts, R. G. and Spooner, N. A. 1993 Dating loess up to 800 ka by thermoluminescence. Comment and reply. Geology 21: 568-569. 